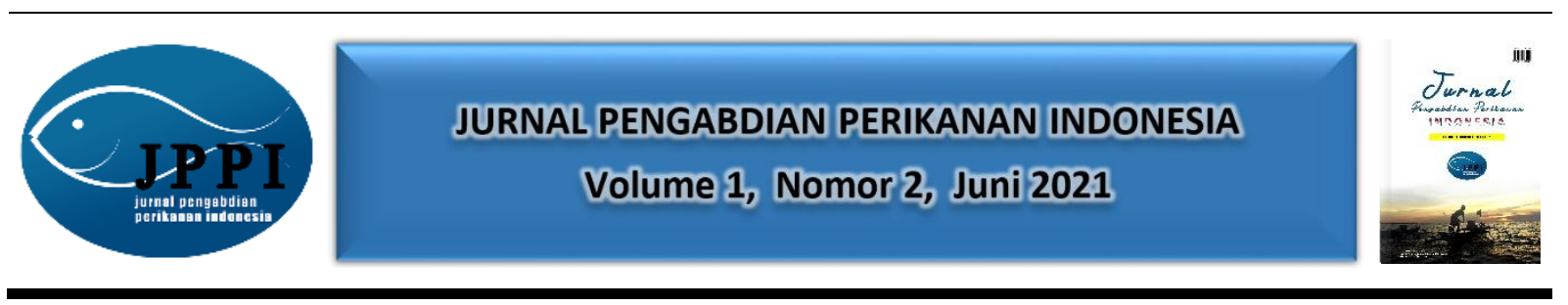

\title{
PENGOLAHAN RUMPUT LAUT UNTUK DIVERSIFIKASI MAKANAN OLAHAN BAGI WISATAWAN DI DESA EKAS BUANA
}

\author{
Nanda Diniarti ${ }^{\left.{ }^{*}\right)}$, Baiq Lizawati ${ }^{2)}$, Baiq Retno Wulandari ${ }^{2)}$, Ananda Rosalina ${ }^{2)}$, Sopiyan Hadi ${ }^{3)}$, \\ Mukhlisatun ${ }^{4}$
}

${ }^{1}$ Program Studi Budidaya Periran Fakultas Pertanian, Universitas Mataram, ${ }^{2}$ Fakultas Hukum, Universitas Mataram, ${ }^{3}$ Fakultas Ekonomi dan Hukum, Universitas Mataram, ${ }^{4}$ Fakultas MIPA, Universitas Mataram

Jalan Majapahit No. 62, Mataram 83125

Alamat korespondensi: nandadiniarti@unram.ac.id

(Tanggal Submission: 3 Desember 2020, Tanggal Accepted : 29 Juni 2021)

\section{Keyword: Abstrak:}

KKN Pantai Ekas merupakan spot wisata bahari yang terkenal dan sering di datangi oleh Tematik, wisatawan baik dari luar Lombok maupun dari pulau Lombok sendiri. Pantai Ekas UHO, Budidaya terletak di Desa Ekas Buana Kecamatan Jerowaru Lombok Timur. Adanya kunjungan wisatawan ke Pantai Ekas membuat peluang usaha kuliner yang berbasis bahan dasar yang banyak terdapat di Desa Ekas Buana. Sebagai wilayah pesisir Desa Ekas Buana memiliki sumberdaya hayati yang kaya, salah satunya rumput laut yang banyak tumbuh di pantai dan ada pula kegiatan budidaya rumput laut jenis Eucheuma cottonii di bulan tertentu.Pengolahan rumput laut kering menjadi puding mejadi pilihan pada pelatihan yang diadakan. Kegiatan pelatihan pengolahan dilakukan pada tanggal 9 Februari 2021 bertempat di kediaman Pak Rumawe. Kegiatan merupakan bagian dari Kuliah Kerja Nyata (KKN) Universitas Mataram Era New Normal. Tujuan dari pelatihan ini adalah meningkatkan keterampilan ibu-ibu dalam mengolah rumput laut kering. Metode palaksanaan kegiatan meliputi pelatihan dan diskusi. Hasil pelatihan berupa meningkatnya pengetahuan dan keterampilan ibu-ibu dalam mengolah rumput laut kering menjadi pudding. Puding gula merah yang dihasilkan pada pelatihan memiliki tekstur yang kokoh dan rasa yang enak. Untuk kemasan disarankan menggunakan cup khusus puding agar lebih higienis dan mudah dibawa oleh wisatawan.

Panduan Sitasi (APPA $7^{\text {th }}$ edition) :

Diniarti, N., Lizawati, B., Wulandari, B.R., Rosalina, A., Hadi, S., \& Mukhlisatun. (2021). Pengolahan Rumput Laut Untuk Diversifikasi Makanan Olahan Bagi Wisatawan Di Desa Ekas Buana. Jurnal Pengabdian Perikanan Indonesia, 1 (2), 98-102. http://doi.org/ 10.29303/jppi.v1i2.132 


\section{PENDAHULUAN}

Desa Ekas Buana merupakan salah satu desa yang termasuk dalam Kecamatan Jerowaru Lombok Timur. Secara administrasi Desa Ekas Buana memiliki batasan di Utara dengan Desa Pemongkong, bagian Selatan berbatasan dengan Laut Samudra Indonesia, bagian timur berbatasan dengan Desa Kwang Rundun dan Seriwe dan sebelah barat berbatasan dengan Teluk Ekas (Kab. Lombok Timur, 2018). Sebagai desa yang berada di daerah pesisir maka sebagian besar penduduk Desa Ekas Buana merupakan Nelayan baik sebagai nelayan tangkap maupun pembudidaya ikan serta petani wilayah kering (Ghazali et al.2021). Teluk Ekas memiliki banyak potensi sumberdaya yag bisadigali baik dari segi biota maupun keindahannya. Penduduk Desa Ekas Buana merupakan pembudidaya rumput laut ( Diniarti et al., 2018), ikan kerapu maupun lobster. Namun beberapa tahun ini keindahan Pantai ekas telah banyak juga menyedot perhatian dan didatangi oleh wisatawan local, dalam negeri maupun manca negara. Beberapa spot wisata yang di datangi antara lain Pantai Kura-kura, pantai planet sebagai tempat selancar dan Ekas Adventure yang merupakan Restoran terapung.

Banyaknya wisatawan yang datang mengunjungi tempat wisata di Desa Ekas Buana merupakan peluang bagi ibu-ibu untuk menyediakan kuliner. Kuliner yang disediakan hendaknya merupakan hasil pertanian maupun perikanan dari Desa sehingga mudah dalam pemenuhan bahan baku serta dapat menambah nilai tambah dari hasil pertanian dan perikanan. Hasil perikanan yang selama ini banyak terdapat di pantai dan dihasilkan oleh nelayan budidaya adalah rumput laut jenis Eucheuma Cottonii (Cokrowatiet al., 2019). Rumput laut merupakan bahan baku makanan yang bisa digunakan untuk berbagai macam olahan dan memiliki nutrisi yang baik untuk kesehatan (Erniati et al., 2016 dalam Cokrowati et al.,2020). Olahan rumput laut yang sering di konsumsi adalah puding. Namun biasanya kita mengolah pudding dari bubuk rumput laut jenis Gracillaria sp. sehingga butuh pengetahuan dalam membuat pudding yang berasal dari rumput laut kering $E$. cottonii. Tujuan dari kegiatan ini adalah meningkatkan keterampilan ibu-ibu dalam mengolah rumput laut kering menjadi pudding.

\section{METODE PELAKSANAAN}

Kegiatan pelatihanini merupakan bagian dari kegiatan mahasiswa KKN era New Normal. Pelatihan dilakukan dengan menggunakan metode pendidikan orang dewasa berupa tutorial dan praktek langsung pembuatan puding rumput laut. Pelaksanaan pelatihan mengikuti protocol covid sehingga peserta yang mengikuti jumlahnya dibatasi.

Kegiatan dilakukan dengan praktek langsung bersama peserta kegiatan membuat puding rumput laut. Berikut adalah bahan, peralatan dan langkah pembuatan pudding rumput laut kering. Tabel 1. Alat dan Bahan yang digunakan untuk membuat pudding rumput laut kering

\begin{tabular}{ll}
\hline \multicolumn{1}{c}{ Alat } & \multicolumn{1}{c}{ Bahan } \\
\hline 1. Panci & 1. $1 / 4 \mathrm{~kg}$ rumput laut kering \\
2. Pisau & 2. $1 / 2 \mathrm{~kg}$ Gula merah \\
3. Kompor dan gas & 3. 2 liter santan sedang \\
4. Baskom & 4. 1 liter air biasa \\
5. Parutan & 5. Secukupnya garam \\
6. Saringan & 6. Daun Pandan \\
7. Talenan & \\
8. Cetakan/loyang & \\
\hline
\end{tabular}


Langkah Pembuatan.

1. Cuci rumput laut kering sebanyak 6 kali dengan air tawar yang mengalir dan potong-potong kecil.

2. Potong-potong gula merah agar mudah larut.

3. Didihkan air biasa dalam panci, setelah mendidih masukkan gula. Masak hingga gula larut.

4. Setelah gula larut saring cairan gula agar ampasnya hilang

5. Masak lagi larutan gula yang telah disaring dan daun pandan sampai mendidih kemudian masukkan santan dan rumput laut kering. Aduk-aduk terus agar santan tidak pecah dan tambahkan sedikit garam. Masak hingga 15 menit.

6. Saring larutan pudding agar pudding yang dihasilkan lembut pada Loyang/cetakan. Usahakan menyaring secepatnya karena larutan sangat kental.

\section{HASIL KEGIATAN}

Kegiatan dilaksanakan di Desa Ekas Buana Kecamatan Jerowaru Kabupaten Lombok Timur pada tanggal 9Februari 2020. Lokasi pelaksanaan kegiatan di kediaman bapak Rumawe. Peserta dan sasaran pelatihan ini adalah ibu rumah tangga dan remaja puteri. Pelatihan di hadiri oleh 7 peserta (gambar 1). Minimnya peserta karena kegiatan dilaksanakan mengikuti protocol covid sehingga peserta yang mengikuti di batasi dan dilakukan di ruangan terbuka. Selain itu waktu pagi hari beberapa ibu-ibu dan remaja putri pergi bekerja.

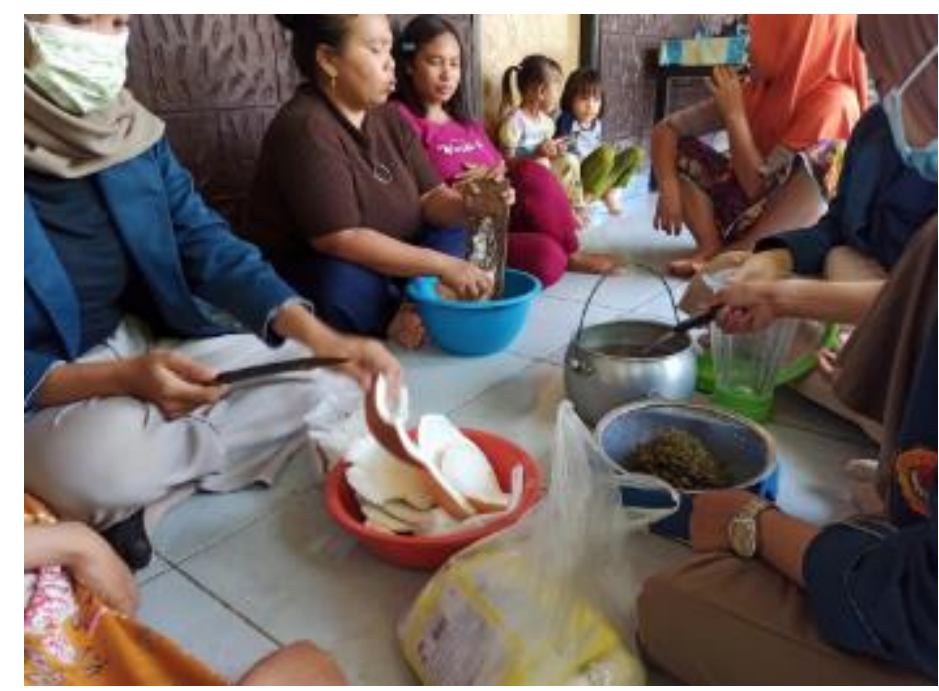

Gambar 1. Kegiatan pengolahan rumput laut kering menjadi pudding

Bahan baku rumput laut kering di dapatkan dari Desa Ekas Buana yang merupakan sentra budidaya rumput laut di Lombok Timur. Namun jumlahnya hanya terbatas karena dalam mengolah rumput laut kering menggunakan air tawar untuk merendam dan membilas rumput laut. Desa Ekas Buana terbatas jumlah air tawar karena air tanah masih terkena pengaruh laut sehingga bersifat air payau. Selama ini rumput laut basah hanya di konsumsi segar seperti dibuat olahan plecing dan urapan, sedang rumput laut kering biasanya di gunakan untuk bahan campuran es buah.

Kegiatan dimulai dengan melontarkan diskusi tentang cara pengolahan rumput laut yang telah dilakukan oleh ibu-ibu sambil memberikan informasi bahwa olahan makanan dari rumput laut sekarang ini sudah sangat beragam. Selain itu mahasiswa KKN juga memberikan informasi penting 
tentang rumput laut yang banyak mengandung mineral berupa kalsium dan protein sehingga bias menyokong kebutuhan nutrisi anak-anak dan orang dewasa.

Olahan puding merupakan cemilan atau kudapan yang biasanya dihidangkan secara dingin karena memberi rasa menyegarkan dan mengenyangkan karena mengandung gula dan serat. Selain itu dalam mengolah rumput laut menjadi puding membutuhkan alat yang relative sederhana dan dimiliki oleh semua ibu rumah tangga. Pada pudding kali ini menggunakan santan karena kelapa banyak terdapat di Desa pelatihan dan rasa yang diberikan akan lebih gurih. Tekstur pudding yang dihasilkan pada pelatihan kali ini bersifat kokoh dan tidak mudah hancur serta berasa manis legit yang didapatkan dari kombinasi gula merah dan santan (gambar 2).
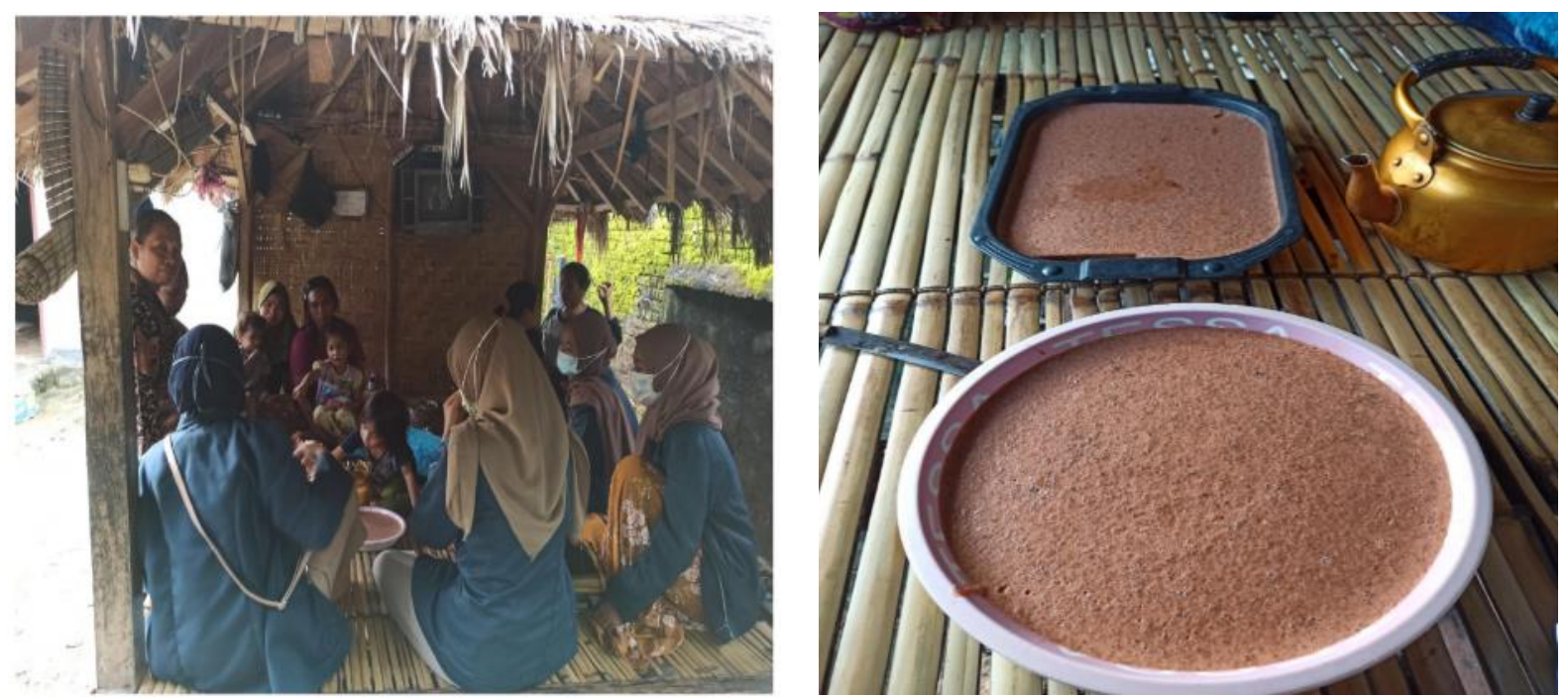

Gambar 2. Pendinginan dan hasil olahan rumput laut kering

Ibu-ibu yang mengikuti pelatihan bertanya akan jenis rumput laut apa lagi yang bisa di buat puding atau bahasa lokalnya agar-agar. Rumput laut untuk bahan dasar mengolah pudding bisa menggunakan Gracillaria atau nama lokalnya "sango-sango" dan Gellidium. Rumput laut Gellidium jarang di budidayakan di pesisir Lombok namaun sango-sango mudah ditemui bahkan menyjadi biofouling di Keramba Jaring Apung. Cara mengolah rumput laut jenis lain menjadi pudding/agaragar pun sama hanya saja kekentalan pudding yang akan berbeda dengan yang dibuat dari $E$. cottonii.

Puding pelatihan di cetak dalam Loyang besar sehingga butuh di potong saat akan disajikan. Ini tidak apa-apa jika hanya menjadi konsumsi keluarga. Bila pudding akan dijual maka sebaiknya kemasan yang digunakan adalah kemasan satuan/ berupa cup-cup pudding yang telah banyak beredar di pasaran. Pengemasan dalam kemasan satuan akan lebih higienis dan mudah dibawa oleh pembeli atau wisatawan.

\section{KESIMPUAN DAN SARAN}

\section{Kesimpulan}

Pelatihan pengolahan rumput laut kering menjadi pudding telah dilaksanakan dan ibu-ibu peserta pelatihan telah terampil mengolah serta bisa mengkreasikan menjadi jenis pudding selain 
resep yang diberikan. Pengolahan rumput laut menjadi pudding tidak hanya dari jenis rumput laut $\mathrm{E}$. cottonii tapi dapat juga dengan Gracillaria atau Sango-sango.

\section{Saran}

Diharapkan ada pengolahan jenis lain dari rumput laut dan hasil perikanan lainnya di lain waktu dan membuat beberapa gelombang dan mengakomodir semua disun yang ada di Desa Ekas Buana.

\section{DAFTAR PUSTAKA}

Cokrowati N., N. Diniarti, D.N. Setyowati, S. Waspodo, M. Marzuki. 2019. Eksplorasi dan Penangkaran Bibit Rumput Laut (Eucheuma cottonii) di Perairan Teluk Ekas Lombok Timur. JUrnal Biologi Tropis, 19(1).

Cokrowati, N., Andriani, R., \&Marzuki, M. 2020. Pengolahan Rumput Laut Sebagai Camilan Sehat Di Desa Seriwe Kecamatan Jerowaru Kabupaten Lombok Timur. Jurnal Pengabdian Magister Pendidikan IPA, 3(2).

Diniarti, N., D.N. Setyowati, A.A. Damayanti, M. Junaidi., I. Rahman. 2018. Sosialisasi kedalaman yang optimal bagi pertumbuhan dan kualitas rumput laut Eucheuma cottonii di Desa Ekas Buana Kabupaten Lombok Timur. Jurnal Abdi Insani, 5(2).

Ghazali, M., Rabbani, R., Sari, M., Rohman, M. H., Nasiruddin, M. H., Suherman., \& Nurhayati. (2021). Pelatihan Pengolahan Kerupuk Ikan di Desa Ekas Buana Kecamatan Jerowaru Kabupaten Lombok Timur. Jurnal Pengabdian Magister Pendidikan IPA, 4(2).

Kabupaten Lombok Timur. 2018. Peraturan Bupati Lombok Timur No.19 Tahun 2018 Tentang batas Desa Ekas Buana Kecamatan Jerowaru Kabupaten Lombok Timur.https://jdih.lomboktimurkab.go.id > produk-hukum-pet...[diakses 20-06-2021] 